\title{
PROTEÇÃO JURÍDICA DE DADOS PESSOAIS: A INTIMIDADE SITIADA ENTRE O ESTADO E O MERCADO
}

\author{
LEGAL PROTECTION OF PERSONAL DATA: INTIMACY LAID SIEGE \\ BETWEEN THE STATE AND THE MARKET
}

\author{
por José Antônio Peres Gediel** \\ Adriana Espíndola Corrêa**
}

\begin{abstract}
RESUMO: A necessidade de proteção jurídica dos dados pessoais, suscitada pelas tecnologias da informação, opera uma mudança no conceito de direito à intimidade, que passa a ser entendido como o direito de o titular controlar os fluxos de suas informação. No entanto, a tutela jurídica da intimidade permanece centrada no consentimento do titular, com exceções justificadas pelo interesse público. Nesse modelo, desconsidera-se a importância da informação na distribuição dos poderes sociais. E, em uma sociedade pronta a renunciar seus direitos em nome da segurança e da participação no mundo tecnológico, acabam por prevalecer os interesses do mercado e as razões de Estado.
\end{abstract}

PALAVRAS-CHAVE: proteção jurídica dos dados pessoais; tecnologias da informação; direito à intimidade.

* Professor Adjunto de Direito Civil da Faculdade de Direito da UFPR, coordenador do Grupo de pesquisa BIOTEC - Biotecnologia, Direito e Sociedade e do Projeto de Pesquisa PROCAD-AMAZÔNIA/CAPES "A proteção jurídica da biodiversidade na Amazônia brasileira e nos países integrantes do Tratado de Cooperação Amazônica".

**Doutoranda do Programa de Pós-graduação em Direito da UFPR, bolsista do CNPQ, pesquisadora do Grupo de pesquisa BIOTEC - Biotecnologia, Direito e Sociedade e do Projeto de Pesquisa PROCADAMAZÔNIA/CAPES “A proteção jurídica da biodiversidade na Amazônia brasileira e nos países integrantes do Tratado de Cooperação Amazônica".
ABSTRACT: The necessity of law protection of personal data, raised by the information technologies, changed the concept of right to privacy, that now on is understood as the right to control the own information's flows. Nevertheless, the law protection of privacy is still centered on individual consent, with some exception justified by public interests. This model disregards the importance of information in the distribution of social power. And, in a society ready to renounce rights in the name of security and of the participation in the technological world, the market's interests and the State's reasons end by prevailing.

KEYWORDS: legal protection of personal data; information technologies; right to privacy.

RÉSUMÉ: La nécessité de protection juridique, suscitée par les technologies de l'information, a modifié le concept de droit à la vie privée, qui passe à être compris comme le droit de contrôle sur les flux d'informations personnelles. Toutefois, la protection juridique de la vie privée est encore centrée dans le consentement individuel, excepté par l'intérêt public. Ce model ne prend pas en compte l'importance de l'information dans la distribution des pouvoirs sociaux. Et, dans une société prête à renoncer des droits au nom de la sécurité et de la participation dans le monde technologique, les intérêts du marché et les raisons d'État finissent par prévaloir.

MOTS CLÉS: protection juridique des données personnelles; technologies de l'information; droit à la vie privée. 
Nous abidquons notre individualisme de peur de le voir menacé. ${ }^{l}$

As tecnologias da informação suscitam preocupações quanto à proteção da intimidade há pelo menos três décadas. Elas pareciam nos remeter aos pesadelos das distopias do Big Brother e do Brave New World - obras, aliás, constantemente citadas em artigos sobre o tema. Hoje, com a massificação dessas tecnologias, embora a questão permaneça nas pautas política e jurídica, temos a impressão de que o medo arrefeceu. A realidade se apresenta menos terrível do que a descrita por Orwel ou Huxley. Menos terrível e mais sutil. Todavia, não menos preocupante.

A proteção dos dados pessoais é uma questão específica das sociedades contemporâneas, nas quais a informação assume importância fundamental na política e na economia. Ela foi associada nas últimas décadas, sobretudo na Europa e nos Estados Unidos, com a tutela da intimidade ou da privacy. ${ }^{2} \mathrm{E}$, nesse

1 Tradução livre: "Nós abdicamos nosso individualismo por medo de lhe ver ameaçado". (EDELMAN, Bernard. L'homme numérique: questions d'image. In INSTITUT SUISSE DE DROIT COMPARÉ; UNIVERSITÉ DE LAUSANNE. L'individu face aux nouvelles technologie: surveillance, identification et suivi. Lausanne: Schulthess, 2005. p. 43).

2 A literatura jurídica costuma distinguir o direito à intimidade do direito à vida privada. $\mathrm{O}$ primeiro destina-se à proteção da esfera mais restrita do indivíduo e permite a exclusão da intromissão mesmo de pessoas mais próximas, como integrantes da família. Tanto no Direito alemão como no francês, a intimidade é referida como esfera mais nuclear da vida privada. No direito norte-americano, a expressão intimacy (intimidade) designa as relações íntimas entre as pessoas, em especial de natureza sexual, enquanto o conceito privacy foi pensado, de início, como o direito ao isolamento (the right do be left alone); com o desenvolvimento tecnológico, principalmente das telecomunicações e da informática, seu significado é ampliado para abranger o controle do sentido, o debate jurídico gira em torno da necessidade de transformação desse conceito gestado no século XIX às especificidades do tratamento de dados possibilidados pelas tecnologias da informação.

Stefano Rodotà, já no final da década de 1970, alertava para uma mudança profunda no conceito e na função da privacy provocada por esse debate:

Quem sabe decifrar o debate em curso, de fato, se apercebe que nesse não se reflete apenas o clássico tema da defesa da esfera privada contra a invasão do exterior, mas se realiza uma importante mudança qualitativa, que impele a considerar o problema da privacy antes no quadro da atual organização do poder, cuja a infra-estrutura informativa representa, de agora em diante, precisamente um dos componentes fundamentais. ${ }^{3}$

A intimidade foi pensada pelo Direito Moderno, de início, como um direito vinculado à propriedade individual. Foi desse modo que se pensou a proteção da privacidade como vedação da violação do domicílio, bem como se desenvolveu a idéia de inviolabilidade da correspondência.

acesso e fluxo de dados pessoais. Devida a essa imprecisão terminológica, Danilo Doneda sugere adotar o termo "privacidade" para "unificar os valores expressos pelos termos intimidade e vida privada" (DONEDA, Danilo. Da privacidade à proteção de dados pessoais. Rio de Janeiro: Renovar, 2006. p. 112). Neste artigo, utilizaremos os termos intimidade, privacidade e privacy como sinônimos.

3 Tradução livre do original: "Chi sa decifrare il dibattito in corso, infatti, si accorge che in esso non si riflette soltanto il classico tema della difesa della sfera privata contro le invasioni dall'esterno, mas si realizza un importante cambiamento qualitativo, che spinge a considerare i problemi della privacy piuttoso nel quadro dell'atualle organizzazione del potere, di cui appunto l'infrastrutura informativa rappresenta ormai una delle componenti fondamentali." (La "privacy" tra individuo e collettività. In RODOTÀ, Stefano. Il diritto privato nella società monderna. Bologna: Mulino, 1977. p. 159). 
No final do século XIX, a conhecida formulação norte-americana do right to be left alone vincula a proteção da intimidade à tutela da liberdade individual, em confronto, sobretudo, com a liberdade de imprensa. Tratava-se de garantir um espaço reservado ao indivíduo em relação às crescentes ingerências da sociedade massificada e dos meios de comunicação.

No Direito europeu continental, a elaboração dos direitos de personalidade, ao longo do século XX, confere novos contornos ao direito à intimidade e à vida privada, que passa a ser compreendido como direito extrapatrimonial, que tem por fim a proteção da pessoa e de seus diversos "modos de ser".

Em ambos os casos, a intimidade passa a ser vista como elemento fundamental na proteção da liberdade e autonomia pessoais. A tutela da vida privada e da intimidade implica a delimitação de um espaço de autonomia no que concerne a aspectos existenciais do ser humano, a fim de se garantir a liberdade individual contra ingerências indevidas da sociedade ou do Estado.

Em um primeiro momento, no contexto da sociedade moderna individualista, a proteção da intimidade revela-se na proibição de acesso a determinados dados e informações que se insiram na esfera privada da pessoa. Garantia-se, assim, o direito de manter segredo sobre determinadas questões como relações familiares, orientação religiosa, política e sexual, proteção ao domicílio, o sigilo telefônico e epistolar etc.

No entanto, com desenvolvimento tecnológico, a complexidade das relações sociais exigiu uma nova concepção de intimidade e de qual tutela the deve ser atribuída. O tratamento jurídico pressupõe a inevitabilidade do aumento do fluxo de dados pessoais em razão da interação global promovida pelas tecnologias da telecomunicação e da informática. De um lado, relativiza-se a intimidade, ampliando-se a possibilidade de acesso a dados e informações de natureza pessoal; de outro, busca-se fortalecer a proteção da pessoa inserindo nos poderes do titular desse direito de personalidade o controle não só sobre o acesso, mas também no que se refere ao seu tratamento, à sua utilização e à sua circulação.

Na sociedade tecnológica contemporânea, dessa forma, a construção da esfera privada passou a ser compreendida pela possibilidade de o indivíduo controlar o acesso e o uso dos dados que constituem sua identidade pessoal e permitem o livre desenvolvimento de sua personalidade (tais como: opinião política, convicções religiosas, vida sexual, dados de saúde e dados genéticos). Em suma, mais do que garantir o segredo sobre esses dados, o problema foi pensado em termos de como assegurar o controle do fluxo dessas informações.

Neste ponto, importa delinear minimamente o que se entende por dados e informações pessoais. No artigo $2^{\circ}$, "a" da Diretiva 95/46/CE do Conselho da Europa, que disciplina a matéria e serviu de base para elaboração de leis nacionais em toda a Europa, os dados pessoais são definidos como:

... qualquer informação relativa a uma pessoa singular identificada ou identificável («pessoa em causa»); é considerado identificável todo aquele que possa ser identificado, directa ou indirectamente, nomeadamente por referência a um número de identificação ou a um ou mais elementos específicos da sua identidade física, fisiológica, psíquica, económica, cultural ou social. 
Outro conceito importante presente na Diretiva 95/46/CE é o de "tratamento de dados pessoais", definido da seguinte forma:

... qualquer operação ou conjunto de operações efectuadas sobre dados pessoais, com ou sem meios automatizados, tais como a recolha, registro, organização, conservação, adaptação ou alteração, recuperação, consulta, utilização, comunicação por transmissão, difusão ou qualquer outra forma de colocação à disposição, com comparação ou interconexão, bem como o bloqueio, apagamento ou destruição (art. 2', "b").

A idéia de tratamento é relevante, porque é justamente essa possibilidade de trabalhar os dados e informações, por meio da tecnologia da informática e das telecomunicações que lhes agrega elevado valor político e econômico.

A noção de dados pessoais é bem ampla e abrange toda e qualquer informação referente a uma pessoa identificada ou identificável ${ }^{4}$. Nisso incluem-se, é claro, o nome, o endereço, o telefone, os números dos documentos de identificação, mas também currículos escolares, dados profissionais, fiscais e bancários, dívidas e créditos, meios de pagamento, o endereço eletrônico, o IP (Internet Protocol-que permite a identificação do usuário de computador), imagens recolhidas por câmeras de segurança, fotografias disponibilizadas na Internet, e, ainda, hábitos de consumo, dados de saúde e biométricos.

4 Por conseguinte, excluem-se da categoria de dados pessoais os dados anônimos, como os dados estatísticos que não estão ligados a uma pessoa identificada ou identificável. A definição do que seja uma pessoa "identificável” é pautada no princípio da proporcionalidade. Assim, não se consideram dados pessoais aqueles que para a identificação da pessoa de origem sejam necessários medidas desproporcionais (CASTRO, Catarina Sarmento e. Direito da informática, privacidade e dados pessoais. Coimbra: Almedina. 2005, p. 72).
O Direito europeu, na esteira da orientação do Conselho da Europa e, em especial, da referida Diretiva, confere especial proteção a determinados dados que denotam maior suscetibilidade e potencialidade discriminatória, por revelarem informações sobre a origem racial ou étnica, as opiniões políticas, as convicções religiosas ou filosóficas, a filiação sindical, a vida sexual e os dados de saúde, inclusive genéticos. ${ }^{5}$

Em relação a esses dados, que tocam diretamente à intimidade da pessoa, se estabelece como regra a proibição de tratamento, que só pode ser realizado, de forma excepcional e com especiais medidas de segurança, mediante consentimento do titular ou em caso de previsão expressa de lei. É o caso, por exemplo, das pesquisas científicas e da coleta de dados para elaboração de políticas públicas.

Stefano Rodotà sustenta que com o incremento da coleta e tratamento de dados pelo poder público e pelas empresas é preciso repensar a função da privacy: de um direito burguês que vincula intimidade à propriedade, seria necessário refletir sobre em que medida a proteção dos dados pessoais pode assegurar a igualdade de tratamento dos cidadãos. Aqui a intimidade é chamada para a defesa de interesses não individualistas, mas de interesse da participação democrática na sociedade. ${ }^{6}$

5 É o que dispõe o art. $8^{\circ}$ da Diretiva 95/46/CE: “1. Os Estados-membros proibirão o tratamento de dados pessoais que revelem a origem racial ou étnica, as opiniões políticas, as convicções religiosas ou filosóficas, a filiação sindical, bem como o tratamento de dados relativos à saúde e à vida sexual".

6 RODOTÀ, Stefano. La "privacy” tra individuo e colletività... p. 164-165. 
Para contextualizar a questão, cumpre realçar que a tutela dos dados pessoais sofre dois principais vetores de pressão, típicos da sociedade contemporânea, na qual a informação constitui elemento central tanto no controle social como na produção de riquezas. Primeiro, a pressão do Estado para aumentar a quantidade e a qualidade de informações sobre os cidadãos, bem como para garantir a segurança e a saúde públicas. Segundo, a pressão do mercado, tendo em vista o valor econômico dos dados sobre consumidores.

A complexidade e relevância da questão são incrementadas pela configuração da sociedade de controle, marcada pela importância crucial das informações tanto pessoais como impessoais. A tecnologia digital e dos meios de comunicação permite, quase de forma ilimitada, a recolha seletiva e à distância, o armazenamento, a classificação, a recombinação e o cruzamento de uma grande quantidade de informações, que possibilitam a construção de perfis de cidadãos e consumidores.

A lógica da sociedade de controle foi teorizada por Gilles Deleuze, que explicita as diferenças entre esta e a sociedade disciplinar analisada por Foucault:

Nas sociedades de controle, ao contrário, o essencial não é mais uma assinatura e nem um número, mas uma cifra: a cifra é uma senha, ao passo que as sociedades disciplinares são reguladas por palavras de ordem (tanto do ponto de vista da integração como da resistência). A linguagem numérica do controle é feita de cifras, que marcam o acesso à informação, ou a rejeição. Não se está mais diante do par massaindivíduo. Os indivíduos tornaram-se dividuais, divisíveis, e as massas tornaram-se amostras, dados, mercados ou "bancos". 7

7 DELEUZE, Gilles. Post-scriptum sobre as sociedades de controle. In: Gilles Deleuze: conversações. Rio de Janeiro: Editora 34, 1992, p. 222.
E em outro texto anuncia:

Estamos entrando nas sociedades de controle, que funcionam não mais por confinamento, mas por controle contínuo e comunicação instantânea ${ }^{8}$

Nesse contexto, as informações sobre cidadãos e consumidores oferecem mecanismos que se encaixam perfeitamente à lógica da sociedade de controle. Da perspectiva do Estado, notadamente nos países do hemisfério norte, tem-se buscado, sob o fundamento da garantia da segurança pública, incrementar as tecnologias de controle de acessos e saídas a determinados locais e também de circulação de pessoas em lugares públicos pela combinação da tecnologia de codificação de dados biométricos com câmeras de vigilância, do mesmo modo, verificam-se o aumento numérico e a melhoria qualitativa dos bancos de dados de impressões digitais e de DNA à disposição das polícias e outras instâncias estatais de controle social.

Contata-se, contudo, atualmente uma tendência preocupante no sentido de flexibilizar os direitos fundamentais em favor da segurança pública - e a proteção concernente aos dados pessoais constitui ponto nevrálgico nessa questão. Isso se verifica em países os Estados Unidos e nos países europeus, que justificam essas limitações ante a necessidade de combater o terrorismo. ${ }^{9}$ Nos países do hemisfério sul,

8 DELEUZE, Gilles. Controle e devir, In: Gilles Deleuze: conversações..., p. 216.

9 Cf. CASTRO, Catarina Sarmento e. $O$ direito à autodeterminação informativa e os novos desafios gerados pelo direito à liberdade e à segurança no pós 11 de setembro. VIII Congresso Ibero-Amricano de Direito Constitucional, Sevilha, Dezembro 2003. Disponível em: http:/www.us.es/cide/Ponencias/ 
como o Brasil, a escalada da violência também tem servido de justificativa para incrementar os poderes estatais em matéria de segurança pública, ainda que mediante a violação da intimidade. ${ }^{10}$

Do mesmo modo, a valorização da saúde e dos aspectos biológicos do ser humano, estimulada pelo Estado e pela indústria biotecnológica, exige dos sistemas de saúde público e privado um sofisticado tratamento de dados de saúde, a fim de garantir um controle eficaz de epidemias, cura de doenças e melhoria da saúde da população, inclusive com a prática da medicina dita preventiva. ${ }^{11}$

Sem olvidar dos inúmeros aspectos benéficos desse desenvolvimento tecnológico, é indispensável refletir sobre os efeitos de padronização e adequação comportamental

fundamentales/ CatarinaCastro.pdf. Acessado em: 25 mar. 2005).

${ }^{10}$ Nesse sentido, são de mencionar o Projeto de Lei n. ${ }^{\circ}$ 188/99, que prevê a identificação genética de pessoas denunciadas por crimes hediondos, assim como Projeto de Lei n. ${ }^{\circ}$ 3078/2000, que prevê a identificação genética de todas as pessoas para fins de expedição de documentos de identidade e estabelece a competência das Secretarias Estaduais de Segurança para definir critérios sobre a utilização das identificações pessoais.

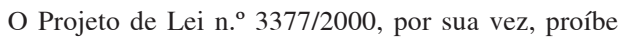
expressamente a utilização do código genético para registro de identificação.

11 Aqui cabe fazer referência ao conceito de biopolítica: Michel Foucault definiu a biopolítica como um conjunto de mecanismos de poder que se exercem sobre a vida humana, em sua dimensão biológica, como indivíduo e como espécie. A biopolítica inclui a vida no terreno das lutas políticas e compreende a população em termos de fenômenos biológicos. Foucault identifica essa mudança de foco nos mecanismos de poder no século XIX, quando gerir vida das populações e dos indivíduos, para incrementála e prolongá-la, passou a ser a tarefa primordial dos governos. (FOUCAULT, Michel. Em defesa da sociedade: curso no Collège de France (1975/1976). São Paulo: 1999, p. 285 e seguintes). dos sujeitos e de controle das populações, decorrentes do estabelecimento de políticas públicas de saúde, formuladas com base em dados pessoais e estatísticos. Aqui, assim como no caso da segurança pública, o modo de tratamento dos dados de saúde anuncia os riscos e possíveis efeitos das tecnologias de digitalização.

Para o mercado, a importância do acesso e uso de dados e informações pessoais é crescente e vital. A formação de perfis de consumidores constitui umas das armas essenciais para a batalha concorrencial, como explica o sociólogo Laymert Garcia dos Santos:

Controlar os consumidores e, principalmente, monitorar as potencialidades de cada uma das dimensões de suas vidas tornam-se uma exigência do próprio processo, impondo a coleta e o tratamento das informações. Ora, se lembrarmos que uma parcela cada vez maior da vida e das atividades do homem contemporâneo tendem a passar pelas redes quem mais bem colocado para acessar os seus dados senão os provedores de acesso ao ciberespaço? Como observa Emilio Pucci, é preciso ter em mente que se por um lado as redes oferecem um enorme fluxo de informações no sentido provedor-usuário, por outro, preciosíssimos fluxos partem desse último para o gestor do serviço, compostos sobretudo de dados relativos aos hábitos e à identidade dos utilizadores. ${ }^{12}$

Tomando-se em consideração esse quadro social é possível pensar as respostas jurídicas

12 SANTOS, Laymert Garcia dos. SANTOS, Laymert Garcia dos. Politizar as novas tecnologias: $o$ impacto sócio-técnico da informação digital e genética. São Paulo: Editora 34. 2003, p. 144. Na mesma lógica operam os mecanismos de modelação e controle de trabalhadores, em um processo dinâmico e permanente, em espaço aberto, e que não se encerram no local e no horário de trabalho (Cf. DELEUZE, Gilles. Postscriptum..., p. 221). 
para a proteção dos dados pessoais. Os modelos de regulação da coleta, acesso e uso dos dados pessoais oscilam entre o liberalismo do Direito norte-americano, que valoriza a escolha individual, e a forte regulamentação estatal dos ordenamentos jurídicos europeus, com fundamento no princípio da dignidade da pessoa humana, mas que não dispensam também o consentimento. ${ }^{13}$

De um modo geral, nos dois continentes, a resposta jurídica consolida-se no sentido de garantir a autonomia individual e proteger a intimidade e a confidencialidade dos dados, com especial atenção à proibição da discriminação. De outro lado, esses dados e informações, situados na esfera jurídica privada, sempre podem ser considerados de interesse público e excepcionados ao controle individual.

Nos países europeus, a preocupação com o equilíbrio entre a proteção da pessoa e os interesses da coletividade e do Estado levou à opção por uma regulação detalhada, na qual foram consagrados, ao lado do consentimento para coleta, alguns princípios que informam o tratamento de dados, constantes de forma exemplar na Diretiva Européia n. 95/46/CE, que podem ser assim esquematizados:

a) princípio da transparência: toda pessoa tem direito à informação por parte do responsável pelo tratamento de dados que lhe digam respeito, inclusive no que tange ao modo, à finalidade, período de conservação etc.; isso implica, também, o direito ao

${ }^{13}$ GRUPE, Fritz H.; KUECHLER, William; SWEENEY, Scott. Dealing with data privacy protection: an issue for the $21^{\text {th }}$ century. In: Information System Management. Volume 19, n. 4. Taylor \& Francis, set. 2002 . pp. 61-70. Disponível em: http://www. informaworld.com. Acessado em: 06 nov 2008. acesso aos próprios dados e ao resultado do tratamento;

b) princípio da finalidade: os dados devem ser utilizados para a finalidade especificamente designada no momento da recolha; a finalidade, por óbvio, deve ser legítima e estar em conformidade com o ordenamento jurídico;

c) princípio da qualidade dos dados: c.1. princípio da legalidade e lealdade (observância da lei e do princípio da boa-fé); c.2. princípio da adequação, pertinência e proporcionalidade em função da finalidade de cada tratamento; c.3. princípio da retidão e atualização dos dados, que assegura ao titular o direito de retificação, apagamento ou bloqueio de seus dados.

No Brasil, o direito de decidir sobre o acesso e fluxo dos dados pessoais deve ser reconhecido tanto com base na proteção da intimidade (art. $5^{\circ}, \mathrm{X}$ da Constituição Federal e art. 21 do Código Civil) como no direito à informação (art. 5º XIV da Constituição Federal). O direito de cada pessoa aceder aos dados que lhe façam referência é pressuposto da garantia do habeas data, previsto no art. $5^{\circ}$, LXXII do texto fundamental.

No plano infraconstitucional, embora o ordenamento jurídico brasileiro não regule de forma sistematizada a proteção dos dados pessoais, podemos encontrar alguns regimes setoriais de tutela, cujo instrumento de proteção privilegiado é o instituto do habeas data. ${ }^{14}$ É o caso, por exemplo, do Código de Defesa do Consumidor,que disciplina os bancos de dados de consumo (artigos 43 e

\footnotetext{
${ }^{14}$ DONEDA, Danilo. Da privacidade... p. 323 e ss.
} 
44), sujeitos aos princípios do direito de acesso, retificação e complementação de suas informações. ${ }^{15}$ A Lei do sigilo das operações financeiras (Lei Complementar n. ${ }^{\circ}$ 105/2001) também veda o acesso aos dados bancários sem consentimento do titular, salvo hipóteses expressas na lei.

Assim, é de ressaltar que os princípios que norteiam o direito europeu podem, embora de forma implícita, ser identificados no nosso ordenamento jurídico. Entretanto, a opção pela ausência de disciplina legislativa, no Brasil, acaba, na prática, por transferir para o mercado a tarefa de auto-regulamentar a matéria, interpolada por intervenções estatais, em geral, marcadas pelo recurso às razões de Estado.

Nesse sentido, é emblemático o caso da cantora mexicana Glória Trevi: sua placenta foi recolhida pela Polícia Federal para realizar o exame do DNA de seu filho, a fim de excluir a paternidade dos policiais federais que haviam sido acusados de estupro pela cantora. O acórdão que deferiu a realização do exame recorre a fundamentos como "razões de Estado", "honra e imagem da instituição", “interesse público", dentre outros. ${ }^{16}$

${ }^{15}$ Cf. MARQUES, Cláudia Lima. Contratos no Código de Defesa do Consumidor: o novo regime das relações contratuais. 4. ed. rev. e ampl. São Paulo: Editora Revista dos Tribunais. 2002, p. 691.

${ }^{16}$ BRASIL. Supremo Tribunal Federal. EMENTA: Reclamação. Reclamante submetida ao processo de Extradição n. ${ }^{o}$ 783, à disposição do STF. 2. Coleta de material biológico da placenta, com propósito de se fazer exame de DNA, para averiguação de paternidade do nascituro, embora a oposição da extraditanda. 3 . Invocação dos incisos X e XLIX do art. $5^{\circ}$, da CF/88, 4. Ofício do Secretário da Saúde do DF sobre comunicação do Juiz Federal da $10^{\circ}$ Vara da Seção Judiciária do DF ao Diretor do Hospital regional da Asa Norte - HRAN,
De qualquer modo, em todos os casos, a regulação jurídica da matéria baseia-se na

autorizando a coleta e entrega da placenta para fins de exame de DNA e fornecimento de cópia do prontuário médico da parturiente. 5. Extraditanda à disposição desta Corte, nos termos da Lei n. ${ }^{\circ} 6.815 / 80$. Competência do STF, para processar e julgar eventual pedido de autorização de coleta de exame de material genético, para fins pretendidos pela polícia Federal. 6. Decisão do Juiz Federal da $10^{\circ}$ Vara do Distrito Federal, no ponto em que autoriza a entrega da placenta, para fins de realização de exame de DNA, suspensa, em parte, na liminar concedida na Reclamação. Mantida a determinação ao Diretor do Hospital Regional da Asa Norte, quanto á realização da coleta da placenta do filho da extraditanda. Suspenso também o despacho do Juiz Federal da $10^{\text {a }}$ Vara, na parte relativa ao fornecimento de cópia integral do prontuário médico da parturiente. 7. Bens jurídicos constitucionais como "moralidade administrativa", "persecução penal pública" e "segurança pública" que se acrescem, - como bens da comunidade, na expressão da Canotilho, - ao direito fundamental á honra $\left(\mathrm{CF}, \operatorname{art.} 5^{\circ}, \mathrm{X}\right)$, bem assim direito à honra e à imagem de policiais federais acusados de estupro da extraditanda, nas dependências da Polícia Federal, e direito à imagem da própria instituição, em confronto com o alegado direito da reclamante à intimidade e a preservar a identidade do pai de seu filho. 8. Pedido conhecido como reclamação e julgado procedente para avocar o julgamento do pleito do Ministério Público federal, feito perante o Juízo Federal da $10^{\mathrm{a}}$ Vara do Distrito Federal. 9. Mérito do pedido do Ministério Público Federal julgado, desde logo, e deferido, em parte, para autorizar a realização do exame de DNA do filho da reclamante, com a utilização da placenta recolhida, sendo, entretanto, indeferida a súplica de entrega à Polícia Federal do "prontuário médico" da reclamante. Vistos, relatados e discutidos estes autos, acordam os Ministros do Supremo Tribunal Federal, em sessão Plenária, na conformidade da ata de julgamento e das notas taquigráficas, por maioria, conhecer do pedido formulado como reclamação e, no mérito, por maioria, julgar procedente a reclamação e, avocando a apreciação da matéria de fundo, deferir a realização do exame de DNA, considerada a placenta da extraditanda e indeferir o acesso ao prontuário médico. Data do julgamento: 21.02.2002. Reclamação n. 2040. Reclamante: Glória de los Ángeles Treviño Ruiz. Reclamado: Juiz Federal da 10 . Vara da Seção Judiciária do Distrito Federal. Relator: Ministro Néri da Silveira. Diário da Justiça da União, Brasília, 27 jun. 2003. 
autonomia privada (consentimento para acesso e tratamento), excepcionada por hipóteses legais de tratamento não consentido, baseadas no interesse público, principalmente em matéria de saúde e segurança públicas.

$\mathrm{Na}$ presente análise, ciente de que isso não esgota outras perspectivas de apreciação necessárias, pretendemos chamar atenção não só para a insuficiência, mas também a conformidade da regulação jurídica no que concerne à lógica do mercado e da sociedade de controle.

Em outras palavras, o modelo de regulação jurídica não só não impede o aprofundamento dos mecanismos de controle que caracterizam a sociedade contemporânea, como também os viabilizam e legitimam. A combinação da regra da autonomia privada com a exceção justificada pelo interesse público, sobretudo na área de segurança e saúde públicas (com hipóteses cada vez mais vagas e amplas), faz convergir a lógica das razões de Estado e a lógica de mercado. ${ }^{17}$

Stefano Rodotà assinala que a passagem esquemática do conceito de intimidade como "right to be left alone" para o poder de controlar o fluxo das informações pessoais põe em destaque o caráter individualista da regulação da matéria. ${ }^{18}$ Uma tal formulação pressupõe certa disponibilidade da pessoa sobre as informações que lhe concernem.

Isso significa que o titular pode, ainda que de forma limitada, dispor desses dados, que passam a ser tomados como bens jurídicos,

17 Até porque não apenas as tecnologias usadas pelos entes estatais e pelos atores privados são as mesmas, como também o Estado é um dos maiores "consumidores" dessas tencologias no mercado.

${ }^{18}$ La "privacy" tra individuo e colletività..., p. 159. objeto de direito, cujo titular é o próprio indivíduo. Em certa medida, o reforço da autonomia sobre o destino dos dados pessoais favorece sua transformação em objetos de relações jurídicas de cunho patrimonial.

A mercantilização dos dados pessoais acarreta a perda da importância de sua dimensão política como instância de proteção da liberdade no espaço público. Relativiza-se, com isso, também a inviolabilidade da intimidade e da vida privada também em face da intervenção do Estado, cuja ingerência se amplia à medida que cresce a exigência de medidas protetivas e preventivas nas áreas de segurança e saúde públicas. ${ }^{19}$

O processo de mercantilização das informações pessoais não é, contudo, automático, pois entre o consentimento do titular e o aproveitamento econômico das informações ocorrem outras operações. Refletindo sobre esse assunto, a partir da obra "A Era do Acesso" de Jeremy Rifkin, Laymert Garcia dos Santos assinala que:

Com a Era do Acesso ocorre, portanto, uma mudança de perspectiva que traz para o centro da atividade econômica o controle sobre o tempo do consumidor. $\mathrm{O}$ consumidor não é mais um alvo mercado, ele torna-se o próprio mercado, cujo potencial é preciso conhecer, prospectar e processar.

(...)

Visando calcular o valor do tempo de vida de um consumidor, projeta-se então o valor

${ }^{19}$ O raciocínio inverso também é pertinente, como aponta um artigo com título sugestivo "Less privacy concern after September $11^{\text {th" }}$ : a relativização da proteção estatal da intimidade dos cidadãos favorece uma percepção menos rigorosa por parte dos particulares em relação à necessidade de proteção da intimidade (ZALUD, Bill. Less privacy concern after September $11^{\text {th }}$. Disponível em: http://findarticles.com/p/articles/mi_hb5568/is_/ai_ n23512579. Acessado em: 20 jun 2007). 
presente de todas as futuras compras contra os custos de marketing e de atendimento investidos para criar e manter uma relação duradoura.

(...)

Otimizar o potencial valor do tempo de vida do consumidor passa então a ser prioridade máxima. Ora, é aqui que a informação torna-se uma arma fundamental. ${ }^{20}$

Pois bem, o acesso a esses dados e informações se dá justamente com o consentimento do consumidor, que ao se cadastrar em sites da internet, abrir contas de e-mail, preencher cadastros etc., disponibiliza desavisadamente seus dados a terceiros.

Catarina Sarmento e Castro noticia o patenteamento de dispositivo que permite a identificação de clientes, em lojas, por dados biométricos dos olhos ou dedos e a subseqüente oferta de produtos de seu interesse, ou seja, a utilização dessa tecnologia para efeitos de marketing. Para isso, é preciso um levantamento de diversos dados pessoais do consumidor que são a ele associados pelo código do dado biométrico. ${ }^{21}$

Basta ler com atenção as chamadas "políticas de privacidade" de alguns provedores de internet, para entender o funcionamento desse mecanismo. Vejamos, a título de exemplo, o que consta da "Política de Privacidade do Gmail":

O Google NÃO lê os seus e-mails. Levamos muito a sério o assunto privacidade. O Gmail é um programa baseado em tecnologia, deste modo a publicidade e as informações relacionadas são exibidas usando um processo totalmente automatizado. Os anúncios são selecionados por relevância e veiculados pelos computadores do Google usando a mesma tecnologia de publicidade de contexto que é a base do programa AdSense. Essa tecnologia

${ }^{20}$ SANTOS, Laymert Garcia dos. Politizar as novas tecnologias..., p. 143.

${ }^{21}$ Direito da informática..., p. 82. permite ao Google direcionar conteúdo de alteração dinâmica, como e-mails ou artigos de notícias diárias.

(...)

Utilizamos os dados pessoais apenas para melhorar o Gmail, fornecendo a você anúncios altamente relevantes e discretos. Suas informações pessoais não serão vendidas ou fornecidas a ninguém, incluindo anunciantes e/ou parceiros comerciais. ${ }^{22}$

Ou seja, a exigência da obtenção do consentimento a garantia da confidencialidade são, em tese, observadas, porque a mensagem não é lida, mas relacionada automaticamente a interesses presumidos do usuário. Mas, ao mesmo tempo, a empresa dispõe de um banco de dados com valor agregado altíssimo.

Aliás, a confidencialidade, ao lado do consentimento, constitui um dos principais mecanismos de proteção da privacidade, como se deduz da regulação jurídica e do debate teórico sobre o tema. Se pensarmos em termos de tutela da intimidade como possibilidade de o indivíduo controlar o fluxo de suas informações pessoais, a anonimização dos dados significaria uma "solução" para o problema.

À primeira vista, parece uma solução conciliadora entre os interesses do mercado, do Estado e do indivíduo. O mercado, de fato, satisfaz-se com a elaboração de um perfil, um feixe de informações que conduz a uma pessoa "anônima". ${ }^{23} \mathrm{O}$ Estado, por sua vez,

${ }^{22}$ Disponível em: www.mail.google.com. Acessado em: 06 nov. 2008.

${ }^{23}$ Sobre a expressão vale transcrever análise de Bernard Edelman: "'Identidade anônima', eu acho a expressão extraordinária. O homem digitalizado seria tão anônimo quanto uma base de dados, um sistema qualquer de informações. Nessa perspectiva, o indivíduo é, ao mesmo tempo, desmaterializado e reduzidos a suas funcionalidades (Tradução livre do original: "'Identité anonyme', je trouve l'expression extraordinaire. L'homme numérique serait aussi anonyme q'une bases 
salvo em questões de segurança pública, tem interesse em dados estatísticos para estabelecer políticas públicas. Insistimos, entrentanto, que essa perspectiva “neutraliza"a dimensão política do controle sobre o acesso e o uso das informações. Ela empurra para fora dos limites do Direito a discussão sobre os poderes sociais associados a esse controle.

A lógica do mercado articula-se com a das razões de Estado, precisamente pelas exceções, ou seja, pela possibilidade dessas empresas disponibilizarem esses dados nos casos previstos em lei e por determinação da autoridade pública. A tendência do aumento das hipóteses de exceção pode ser verificada, de forma paradigmática (quase que como um caso-limite) nos procedimentos norteamericanos, para garantir a segurança nacional contra atos ditos terroristas, dentre eles a exigência em relação às empresas aéreas de conservação dos dados de passageiros, por maior tempo do que o necessário para a prestação de seus serviços. ${ }^{24}$

A estratégia dos instrumentos jurídicos vigentes destinados à proteção da intimidade, calcados na autonomia informativa, ignoram a questão central do controle de informações nas sociedades contemporâneas, ou seja, a distribuição e organização dos poderes sociais:

... a substancial reserva da infra-estrutura informativa a sujeitos privilegiados, sejam públicos ou privados, tem um conseqüência óbvia: a de aumentar a possibilidade de discriminação e de desnível de poder no interior de uma organização social.

de données, qu'un système quelconque d'informations. Dans cette perspective, l'individu est, tout à la fois, dématérialisé et réduit à des fonctionnalités". In: L’homme numérique..., p. 48).

${ }^{24}$ CASTRO, Catarina Sarmento e. $O$ direito à autodeterminação informativa... ob. cit.
(..)

o alargamento da possibilidade e da capacidade de ser informado representa, atualmente, também a premissa de novas estratificações socio-políticas e, portanto, da própria vitalidade democrática de um sistema. ${ }^{25}$

$\mathrm{O}$ alerta de Rodotà torna-se ainda mais pertinente em uma sociedade obscecada pela identificação. Bernard Edelman empregou a expressão "homme numérique" (homem digitalizado) para abordar a questão. A noção de "homme numérique" diz respeito aos processos técnicos de identificação do

25 Tradução livre do original: “... la sostanziale riserva dell' infrastruttura informativa a soggetti privilegiati, pubblici o privati che siano, ha una conseguenza ovvia: quella di accrescetre le possibilità di discriminazione e i dislivelli di potere all'interno di una organizzazione sociale. (...) l'allargamento delle possibilità e della capacità di essere informati rappresenta ormai anche la premessa di nuove strafiticazioni sociopolittiche e, quindi, della stessa vitalità democratica di un sistema" (Rodotà, Stefano. La "privacy" tra individuo e colletività... p. 174). Na sociedade brasileira, a questão é agravada diante da extrema diversidade cultural. Os padrões ocidentais de atuação jurídica são estranhos, por exemplo, aos povos indígenas. Esse estranhamento cultural pôde ser observado no caso da coleta de sangue dos índios kariitana da Amazônia, Parte das pessoas desse povo indigena teve amostras de sangue recolhidas e enviadas para Universidades americanas, bem com depositadas no banco de dados da companhia americana Coriell Cell Repositories. As amostras de DNA continuam a venda pela internet no site desta empresa. Essa comunidade indígena manifestou publicamente sua discordância em relação ao uso de seu sangue, por razões culturais e religiosas. Como é possível facilmente constatar, a questão não pode ser resolvida com recurso ao direito à intimidade, pois o que estava em jogo, de um lado, era a crença cultural e religiosa de todo o grupo e, de outro, seu confronto com os poderes sociais representados pela comunidade científica e as empresas de biotecnologia (Sobre o assunto conferir: VELDEN, Felipe Vander. Quando o sangue se torna mercadoria. In: ComCiência. 10 abr. 2005. Disponível em: http:// www.iande.art.br/textos/sangue.htm. Acessado em: 13 mar. 2008). 
indivíduo por meio de caracteres biológicos ou comportamentais, digitalizados pelas tecnologias da informação.

A proteção da privacy calcada na autonomia e na confidencialidade dos dados esvanece diante da boa vontade dos indivíduos em fornecer seus próprios dados pessoais, motivados pelo desejo de inserção no mundo tecnológico e pelo medo causado pela sensação de insegurança generalizada. Para Edelman, isso é o sinal de uma "esquizofrenia do Direito", que pode ser assim explicada: "De um lado, o indivíduo moderno convoca os direitos fundamentais, de outro, ele está pronto a lhes abandonar para garantir sua segurança. A imagem do homem digitalizado est esta de um homem aterrorizado, que enxerga na técnica sua saúde. Pelo que, ele se transforma a si mesmo em objeto técnico”. ${ }^{26}$

Essa "esquizofrenia" revela mais do que uma mera contradição do sistema jurídico. Ela nos revela indícios de algumas características de nossa cultura:

O homem digitalizado, desse ponto de vista, seria um tentativa desesperada de sair da aflição moderna, que podemos caracterizar triplamente: de início, o terror de um mundo ameaçador, que fervilha de inimigos e que é preciso, a todo preço, identificar: a segurança se torna, então, a palavra-mestre na luta contra o estrangeiro. Em seguida, o terror tecnológico, isto é, o medo de ser excluído de um universo que fervilha de inumeráveis serviços eletrônicos, que criaram suas próprias barreiras; para penetrá-las é preciso se

26 Tradução livre do original: "D'un côté, l'individu moderne en appelle aux droits fondamentaux, de l'autre il est prêt à les abandonner pour assurer sa sécurité. L'image de l'homme numérique est celle d'un homme terrorisé qui voit son salut dans la technique. Par quoi il se transforme lui-même en objet technique" (EDELMAN, Bernard. L'homme numérique..., p. 49). conformar a esse universo, falar sua língua, isto é, se digitalizar. Enfim, conformar-se ao universo tecnológico é tornar-se tanto anônimo, tanto desprovido de alma e de espírito quanto este universo. ${ }^{27}$

Curiosamente, se é a segurança que justifica a renúncia voluntária à própria intimidade, observa-se, ainda que de forma inconfessa, a larga utilização das tecnologias da informação a serviço das exigências o capitalismo contemporâneo de manter o controle sobre consumidores e empregados. Vejamos, por exemplo, a utilização de dispositivos de monitoramento. Em pesquisa de 2002, revelou que as companhias privadas utilizam esses dispositivos principalmente com a finalidade de controle de qualidade do atendimento dos clientes e da produtividade dos empregados; e não tanto por razões de segurança ou de combate ao crime. ${ }^{28}$

Percebemos, assim, a complementariedade dos valores do mercado e das razões da segurança pública, apesar da prevalência dos discursos persuasivos de necessidade de quebra dos direitos fundamentais em nome da segurança. Como constata Edelman:

${ }^{27}$ Tradução livre do original: L'homme numérique, de ce point de vue, serait une tentative désespérée de sortir de la détresse moderne qu'on peut caractériser triplement: tout d'abord la terreur d'un monde menaçant qui fourmille d'ennemis et qu'il faut, à tout prix, identifier: la sécurité devient alors le maître-mot de la lutte contre l'étranger. Ensuite, une terreur technologique, c'est-à-dire la peur d'être exclu d'un univers qui fourmille d'innombrables services électroniques qui ont suscité leurs propres garde-fous; pour y pénétrer, il faut se rendre conforme à cet univers, parler sa langque, c'est-à-dire se faire numériser. Enfin, devenir conforme à l'univers technologique c'est se rendre soi-même aussi anonyme, assui dépourvu d'âme et d'esprit que cet univers (L'homme numérique..., p. 46).

${ }^{28}$ ZALUD, Bill. Less privacy concern after September $11^{\text {th }} \ldots$ ob. cit. 
... não apenas nos faltam outros valores que não os do mercado, mas ainda nós erigimos o indivíduo em valor supremo, enquanto que ele é cada vez mais modelado pelo mercado e é precisamente, no momento em que este indivíduo é confrontado com seu pior inimigo - o terrorista, nascido nos países sub-desenvolvidos ou vias de desenvolvimento-que nós nos abandonamos à segurança policial. ${ }^{29}$

Razões de mercado, razões de Estado. Em uma sociedade cuidadosamente preparada para renunciar ou transferir seu direito de reserva à intimidade, em nome da segurança, da saúde, da herança genética às futuras gerações, tanto quanto em nome de sua inserção no mundo tecnológico, a proteção dos dados pessoais e o domínio sobre o fluxo das informações deve ser pensada sob o prisma de novas formulações da distribuição e do controle dos poderes na sociedade. Para tal, é preciso alterar a racionalidade jurídica que, pela via da autonomia do sujeito, despolitiza o problema da concentração de poder derivada do controle sobre a informação, fazendo prevalecer as racionalidades mercantil e securitária.

\section{REFERÊNCIAS}

CASTRO, Catarina Sarmento e. Direito da informática, privacidade e dados pessoais. Coimbra: Almedina. 2005.

CASTRO, Catarina Sarmento e. O direito à autodeterminação informativa e os novos desafios gerados pelo direito à liberdade e à segurança no pós 11 de setembro. VIII

${ }^{29}$ Tradução livre do original: “... non seulement nous manquons de valeurs autres que celles du marché, mais encore nous érigeons l'individu en valeur suprême alors qu'il est de plus en plus modelé par le marché et c'est précisement, au moment même où cet individu est confronté à son pire ennemi - le terroriste, né dans les pays sous-développés ou en voie de développement - que nous nous abandonnons à la sécurité policière (L'homme numérique..., p. 43).
Congresso Ibero-Amricano de Direito Constitucional, Sevilha, Dezembro 2003. Disponível em: http:/www.us.es/cide/Ponencias/ fundamentales/ CatarinaCastro.pdf. Acessado em: 25 mar. 2005).

DELEUZE, Gilles. Post-scriptum sobre as sociedades de controle. In: Gilles Deleuze: conversações. Rio de Janeiro: Editora 34, 1992. pp. 219-226.

DONEDA, Danilo. Da privacidade à proteção de dados pessoais. Rio de Janeiro: Renovar, 2006.

EDELMAN, Bernard. L'homme numérique: questions d'image. In INSTITUT SUISSE DE DROIT COMPARÉ; UNIVERSITÉ DE LAUSANNE. L'individu face aux nouvelles technologie: surveillance, identification et suivi. Lausanne: Schulthess, 2005. pp. 39-49.

FOUCAULT, Michel. Em defesa da sociedade: curso no Collège de France , p(1975/1976). São Paulo, 1999.

GRUPE, Fritz H.; KUECHLER, William; SWEENEY, Scott. Dealing with data privacy protection: an issue for the $21^{\text {th }}$ century. In: Information System Management. Volume 19, $\mathrm{n}$. 4. Taylor \& Francis, set. 2002 . pp. 61-70. Disponível em: http://www.informaworld.com. Acessado em: 06 nov 2008.

RODOTÀ, Stefano. La "privacy" tra individuo e collettività. In: Il diritto privato nella società monderna. Bologna: Mulino, 1977. pp. 159-185.

\section{MARQUES, Cláudia Lima. Contratos no Código de Defesa do Consumidor: o novo regime das relações contratuais. 4 . ed. rev. e ampl. São Paulo: Editora Revista dos Tribunais. 2002.}

SANTOS, Laymert Garcia dos. SANTOS, Laymert Garcia dos. Politizar as novas tecnologias: o impacto sócio-técnico da informação digital e genética. São Paulo: Editora 34, 2003.

VELDEN, Felipe Vander. Quando o sangue se torna mercadoria. In: ComCiência. 10 abr. 2005. Disponível em: http://www.iande.art.br/textos/ sangue.htm. Acessado em: 13 mar. 2008.

ZALUD, Bill. Less privacy concern after September $11^{\text {th }}$. Disponível em: http://findarticles.com/p/articles/mi_hb5568/is_/ ai_n23512579. Acessado em: 20 jun 2007. 